http://dx.doi.org/10.11646/phytotaxa.116.1.1

\title{
Systematics of Mappia (Icacinaceae), an endemic genus of tropical America
}

\author{
DIEGO F. ANGULO ${ }^{1}$, RODRIGO DUNO DE STEFANO ${ }^{2} \&$ GREGORY W. STULL ${ }^{3}$ \\ ${ }^{1}$ Departamento de Biología Evolutiva, Instituto de Ecologia, A. C., Apartado Postal 63, 91000 Xalapa, Veracruz, Mexico \\ ${ }^{2}$ Herbarium CICY, Centro de Investigación Cientifica de Yucatan, A. C. (CICY), Calle 43 No. 130, Col. Chuburna de Hidalgo, 97200 \\ Merida, Yucatan, Mexico; email: roduno@cicy.mx. \\ ${ }^{3}$ Department of Biology and Florida Museum of Natural History, University of Florida, Gainesville, Florida 32611 USA
}

\begin{abstract}
Mappia includes four species of trees and shrubs distributed in Central America, Mexico and the Greater Antilles. Mappia has historically been associated with the genera Casimirella (=Humirianthera), Icacina, Leretia and Nothapodytes, collectively comprising the Mappia complex, and over the years authors have merged or maintained these genera based on various lines of morphological and anatomical evidence. Here we present a phylogenetic study of the Mappia complex, based on morphological and molecular data, to assess monophyly of Mappia as well as relationships among other icacinaceous genera. Our results indicate that Mappia is sister to the Asiatic genus Nothapodytes, consistent with previous studies, and that Leretia, Icacina and Casimirella form a clade more closely related to other genera of Icacinaceae (e.g., Alsodeiopsis, Iodes, Phytocrene) than to Mappia+Nothapodytes. These results support recognition of Mappia as a distinct entity, and here we provide an updated taxonomic treatment for the genus, recognizing four species including three from Mexico and Central America (M. longipes, M. mexicana, and M. multiflora) and one from the Greater Antilles (M. racemosa).
\end{abstract}

Key words: Caribbean flora, Central American flora, lamiids, Mexican flora, Neotropical flora, $n h d F$

\section{Introduction}

Mappia Jacquin (1797: 22) was forgotten until Miers (1852) assigned many new species mainly from Asia to this genus. Mappia has historically been associated with the Neotropical genus Leretia Vellozo (1829: 99), and both have been treated in different ways. Bentham (1862), Engler (1893), House (1922), Baehni (1936) and Sleumer (1940, 1942) merged these genera. In contrast, Miers (1852), Engler (1893) and Howard (1942) maintained both. Baehni (1936) segregated the Asiatic species of Mappia into a new genus, Neoleretia Baehni (1936: 35) (= Nothapodytes Blume 1850: 248). Howard (1942) provided morphological evidence that these genera are all distinct. More recently, Dahl (1952) provided palynological evidence supporting Leretia and Mappia as distinct entities. House (1922) and Baehni (1936) mentioned that the name Mappia is illegitimate, but the last author proposed to conserve the name, which was agreed in 1940.

Phylogenetic analyses based on morphological data (Kårehed 2001) indicated that Mappia and Leretia are not closely related and that the Asiatic genus Nothapoytes is sister to Mappia, although these analyses did place Mappia+Nothapodytes within a larger clade including Lavigeria Pierre (1892: 267), Leretia, Icacina Jussieu (1823:174), Casimirella Hassler (1913: 249) and Pleurisanthes Baillon (1874: 201). However, several of these genera (i.e., Casimirella, Lavigeria, Leretia and Pleurisanthes) have yet to be included in molecular phylogenetic analyses, and consequently relationships among members of the Mappia complex (Mappia, Nothapodytes, Leretia, Casimirella and Icacina) and other icacinaceous genera, especially Lavigeria, Pleurisanthes, Iodes Blume (1825: 29) and Phytocrene Wallich (1831: 11), remain poorly known. 
Here we present results of a phylogenetic analysis based on morphological and molecular (plastid $n d h F$ ) data to address the following questions: (1) is Mappia monophyletic and with what other genera is it placed within Icacinaceae, especially with respect to other genera of the Mappia complex (Casimirella, Icacina, Leretia and Nothapodytes); and (2) which morphological characters are synapomorphic for Mappia? We also provide an updated taxonomic treatment of Mappia, recognizing four species from Central America, Mexico and the Greater Antilles. Based on this circumscription of Mappia, the genus can be recognized by the following features: trees or shrubs, leaves without stipules, domatia in the abaxial surface of the leaves, malphigiaceous hairs in vegetative and floral structures, inflorescence axillary, bracts and bracteoles absent, flowers pentamerous, petals bearded on their inner surface and ovary surrounded by a disc.

\section{Materials and Methods}

Cartographic maps were produced on a DIVA-GIS base map (Hijmans et al. 2004) using ArcView 3.2 (ESRI 1999) by plotting locality data extracted from available herbarium specimens and relevant literature (Angulo 2006, Duno \& Angulo 2010). This map was later edited with Adobe Photoshop 6.0.1 (Adobe Systems Inc, San Jose, California).

\section{Morphological matrix}

Flowers from herbarium material were soaked in concentrated ammonium hydroxide for about one minute for rehydration and then rinsed in water until soft and ready for study under a dissecting microscope. Flowers thus pretreated were temporarily preserved in a 70:25:5 ethanol:water:glycerine solution for further study and later returned to herbarium sheets. Characters states were obtained from hydrated flowers or direct observation from herbarium material with a Nikon SMZ800 microscope. In the taxonomic treatment, numerical data include the minimal and maximum values; mean and standard deviation are branches.

We used anatomical and pollen information from Karehed (2001); however, most characters turned out to be uninformative in the context of the ingroup-outgroup relationships and therefore were not included in this study. Terminology follows the Systematic Association Committee for descriptive biological terminology (1962) for leaf shape and apex.

A morphological data matrix of 44 characters (Table 1) was produced after careful examination of more than 100 herbarium specimens of Mappia and outgroup taxa from the following herbaria: AAU, BM, CICY, F, G, GOET, HUH, K, MEXU, MO, NY, P, TX, US, XAL and VEN (acronyms according to Thiers 2010). Specimens examined included types of all terminal taxa.

\section{Phylogenetic analysis based on morphological data}

In the phylogenetic analysis based only on morphology, two taxa were designated as outgroups based on previous phylogenetic information (Kårehed 2001): Ottoschulzia pallida Lundell (1912: 272-273) and Oecopetalum mexicanum Greenman \& Thompson (1914[1915]: 408). Regarding the ingroup, four taxa of Mappia were included based on previous data (Angulo 2006, Duno \& Angulo 2010): M. longipes Lundell (1942: 26), M. multiflora Lundell (1970: 139), M. mexicana Robinson \& Greenmam (1895: 50) and M. racemosa Jacquin (1797: 22); we also included other members of the Mappia group-Icacina senegalensis Jussieu (1823: 174), Casimirella Hassler (1913: 249), Leretia cordata Vellozo (1829: 99), Nothapodytes foetida (Wight, 1843-1845: 955) Sleumer (1940: 247) —as well as Lavigeria macrocarpa (Oliver 1866: 357) Pierre (1892: 267) and Pleurisanthes howardii Duno, Riina \& Berry (2002: 13), which formed a clade with members of the Mappia group in previous analyses (Kårehed 2001).

Parsimony analyses of the morphological data set were conducted using PAUP* version 4.0 (Swofford 2003). The analyses included a heuristic search with characters equally weighted and unordered, 1000 replicates with random taxon sequence addition, tree bisection-reconnection branch swapping (TBR), with multiple shortest trees kept during branch swapping, but with no more than 10 trees saved per replicate. We 
also conducted 10000 bootstrap replicates to assess clade support, with random sequence addition, TBR, and 10 trees maximum saved per bootstrap replicate.

TABLE 1. Morphological and palynological characters included in this study.

[0] Plant habit: $0=$ tree, $1=$ shrub, $2=$ liana

[1] Nodal anatomy: $0=$ trilacular, $1=$ unilacular,

[2] Vessel element: $0=$ scalariform perforations; $1=$ porous, simple,

[3] Rhombic crystals in rays of wood; $0=$ absent, $1=$ present

[4] Petiole with abscission line; $0=$ absent, $1=$ present

[5] Blade shape: $0=$ obovate to narrowly obovate, $1=$ ovate to elliptic, $2=$ oblong to narrowly oblong

[6] Apex of blade: $0=$ rounded, $1=$ acute, $2=$ narrowly acute

[7] Pubescence of the blade: $0=$ glabrous, $1=$ strigose

[8] Malpighiaceous hairs: $0=$ absent, $1=$ present

[9] Malpighiaceous hair: $0=$ arms \pm the same length, $1=$ one short arm and one long arm

[10] Domatia: $0=$ absent, $1=$ present

[11] Blade coloration (dry): $0=$ brown, $1=$ green, $2=$ black

[12] Number of secondary nerves: $0=6-7,1=8-9,1=10-12$,

[13] Tertiary reticulation: $0=$ inconspicuous, $1=$ conspicuous

[14] Type inflorescence: $0=$ panicle, $1=$ cyme

[15] Cyme with short secondary axis: $0=$ present, $1=$ absent (long secondary axis)

[16] Reduction inflorescence: $0=$ present, $1=$ absent

[17] Bracteoles: $0=$ absent, $1=$ present (reduced)

[18] Number of flowers per inflorescence: $0=1-4,1=6-50,2=60-100$

[19] Sepals: $0=$ imbricate, $1=$ valvate,

[20] Size of calyx: $0=1 / 4$ length of ovary, $1=1 / 2$ length of ovary,

[21] Calyx persistent: $0=$ yes, $1=$ no

[22] General shape of calyx lobes: $0=$ partite, $1=$ entire, $2=$ lobes weakly dentate

[23] Connation of petals; $0=$ agglutinate at base, $1=$ free

[24] Cylindrical hairs on inner surface of petals; $0=$ absent, $1=$ present

[25] Indumentum in the out surface of the petals: $0=$ absent, $1=$ present

[26] Groves on inner surface of petal: $0=$ absent, $1=$ present

[27] Filament morphology: $0=$ swollen, $1=$ filiform

[28] Size of anther: $0=$ filament \pm equal to anther, $1=$ filament twice the size of anther, $2=$ filament three times longer than anther

[29] Anther dehiscence: $0=$ extrorse, $1=$ introrse

[30] Sagittate anther: $0=$ absent, $1=$ present

[31] Ovary indumentum: $0=$ absent, $1=$ present

[32] Ovary indumentums persistence: $0=$ present at maturity, $1=$ early caducous

[33] Base of the style: $0=$ not swollen, $1=$ swollen

[34] Length of style: $0=$ longer than ovary, $1=$ same length of ovary, $2=$ shorter than ovary

[35] Stigma: $0=$ slightly differentiated, $1=$ capitate,

[36] Disc: $0=$ absent, $1=$ present

[37] Pollen aperture: $0=$ colporate, $1=$ porate,

[38] Numbers apertures (pollen): $0=3,1=4$

[39] Exine enculturation: $0=$ psilate, $1=$ foveolate, $2=$ echinate,

[40] Shape of fruit: $0=$ oblongoid, $1=$ subglobose,

[41] Apex of fruit: $0=$ rounded, $1=$ acuminate

[42] Fruit, laterally compressed: $0=$ absent, $1=$ present

[43] exocarp: $0=$ verrucose, $1=$ smooth

\section{Phylogenetic analysis based on molecular data}

We sampled $n d h F$ sequences for 25 representatives of Icacinaceae (Appendix 1), including newly generated sequences for Calatola cf. venezuelana Pittier (1938: 360) Lavigeria macrocarpum, Leretia cordata, Mappia multiflora, M. mexicana, Oecopetalum mexicanum Greenman \& Thompson (1914[1915]: 408), Ottoschulzia 
pallida Lundell (1975: 105) and Ottoschulzia rhodoxylon Urban (1912: 274). The ingroup sampling includes four representatives of Mappia, allowing us to assess monophyly. However, we were only able to sample three of the four Mappia species recognized here for molecular data because the fourth species, M. longipes, is based on a single specimen that was not available for DNA sampling. Our sampling also includes representatives of all genera of the Mappia complex discussed in the introduction (Mappia, Leretia, Nothapodytes, Casimirella [only morphological data] and Icacina), allowing us to determine relationships among these and other icacinaceous genera. Because the phylogenetic position and circumscription of Icacinaceae remain unresolved (Kårehed 2001), we included a broader sampling of lamiid taxa. Ilex crenata Thunberg in Murray (1784: 168), a representative of the campanulid family Aquifoliaceae, was used as the ultimate outgroup.

DNA was extracted from silica-gel dried (Chase \& Hills 1991) or herbarium material using a modified CTAB protocol (Doyle \& Doyle 1987). We used the primers 972F and 2110R described by Olmstead \& Sweere (1994) to amplify the 3' half of $n d h F$. The PCR reactions included $25 \mu$ l total $(2.5 \mu 110 \mathrm{X}$ buffer, 5.0 $\mu 1$ Q solution (Qiagen), $1.0 \mu 1 \mathrm{MgCl}_{2}(25 \mathrm{mM}), 1.0 \mu \mathrm{l}$ dNTPs $(25 \mathrm{mM}), 1 \mu 1$ each for the $\mathrm{F}$ and $\mathrm{R}$ primers (10mM), $0.2 \mu \mathrm{l} \mathrm{Taq} \mathrm{polymerase,} 1.0 \mathrm{ul}$ DNA template, and $11.3 \mathrm{ul}$ of ddH20), with the following conditions: denaturation at $94^{\circ} \mathrm{C}$ for $4 \mathrm{~min}$, followed by 30 cycles of denaturation at $94^{\circ} \mathrm{C}$ for $45 \mathrm{~s}$, annealing at $49^{\circ} \mathrm{C}$ for $90 \mathrm{~s}$, and extension at $72^{\circ} \mathrm{C}$ for $3 \mathrm{~min}$, with a final extension step at $72^{\circ} \mathrm{C}$ for $7 \mathrm{~min}$. The same primers were used for amplification and sequencing. The newly generated sequences were assembled and edited using Sequencher 4.2.2. (Gene Codes, Ann Arbor, Michigan, USA) and then aligned with additional $n d h F$ sequences from GenBank using Muscle (Edgar 2004), followed by manual adjustment in Se-Al (Rambaut 1996). The 5' portions of the GenBank $n d h F$ sequences were trimmed off to match the sequences generated for this study.

Phylogenetic analyses were conducted using maximum likelihood (ML) in RAxML (Stamatakis 2006) and parsimony in PAUP* version 4.0 (Swofford 2003). The parsimony analyses included a heuristic search with characters equally weighted and unordered, 1000 replicates with random taxon sequence addition, tree bisection-reconnection branch swapping (TBR), with multiple shortest trees kept during branch swapping, but with 10 trees saved per replicate. To assess clade support within a parsimony context, we conducted 10000 bootstrap replicates with random sequence addition, TBR, with 10 trees maximum saved per bootstrap replicate. For the ML analyses in RAxML, the model GTRGAMMA was implemented in the ML searches and bootstrap replicates. Thorough bootstrap and ML searches were conducted together, with bootstrap 1000 replicates. Gaps were treated as missing data in all analyses.

\section{Combined molecular-morphological phylogenetic analyses}

We also conducted combined molecular-morphological phylogenetic analyses, using parsimony in PAUP* version 4.0 (Swofford 2003). For these analyses, we combined the available morphological data (for 12 species of Icacinaceae) with the $n d h F$ sequences. For three taxa (Casimirella, Mappia longipes and Pleurisanthes), we had only morphological data; the molecular characters for these taxa were therefore treated as missing data. Additionally, for 23 other taxa (including other species of Icacinaceae and asterid outgroups) we had available molecular data but no morphological data; thus the morphological characters for these taxa were treated as missing data in the matrix. Multiple studies have shown that missing data are not necessarily problematic in the context of combined molecular-morphological phylogenetic analyses (e.g., Wiens 2003, 2009); therefore, we think this analytical approach should yield reasonable results, and at the least an interesting comparison with the separate morphological and molecular analyses.

For the combined analyses, as with the separate molecular and morphological parsimony analyses, we conducted a heuristic search (including 1000 replicates with random taxon sequence addition, TBR branch swapping, and multiple shortest trees kept during branch swapping, but with 10 trees saved per replicate) to find the most-parsimonious tree(s) as well as 10,000 bootstrap replicates to assess clade support. 


\section{Results}

In the morphological phylogenetic analysis, all 44 characters (Table 1) were informative, and analysis produced a single most-parsimonious tree (Figure 1) with the following statistics: length $(\mathrm{L})=90$, consistency index $(\mathrm{CI})=0.61$, and retention index $(\mathrm{RI})=0.72$. Seven synapomorphies (characters 9, 23, 29, 34, 38, 39, and 40) support the sister relationship of Nothapodytes and Mappia, and monophyly of Mappia is supported by seven synapomorphies (characters 10, 11, 17, 22, 41, 42, 43). Within Mappia, M. racemosa was recovered as sister to the rest of the genus, followed by M. mexicana sister to M. longipes + M. multiflora, although several of these nodes received relatively weak support in the bootstrap analyses (Figure 1). Bootstrap analysis of the morphological data recovered Mappia (bootstrap percentage, BP, 96) as sister (BP 95) to Nothapodytes, but relationships within Mappia were unresolved. Icacina received moderate support (BP 80) as sister to Mappia+Nothapodytes, but placements of the other ingroup taxa included (Leretia, Casimirella, Lavigeria) were unresolved.

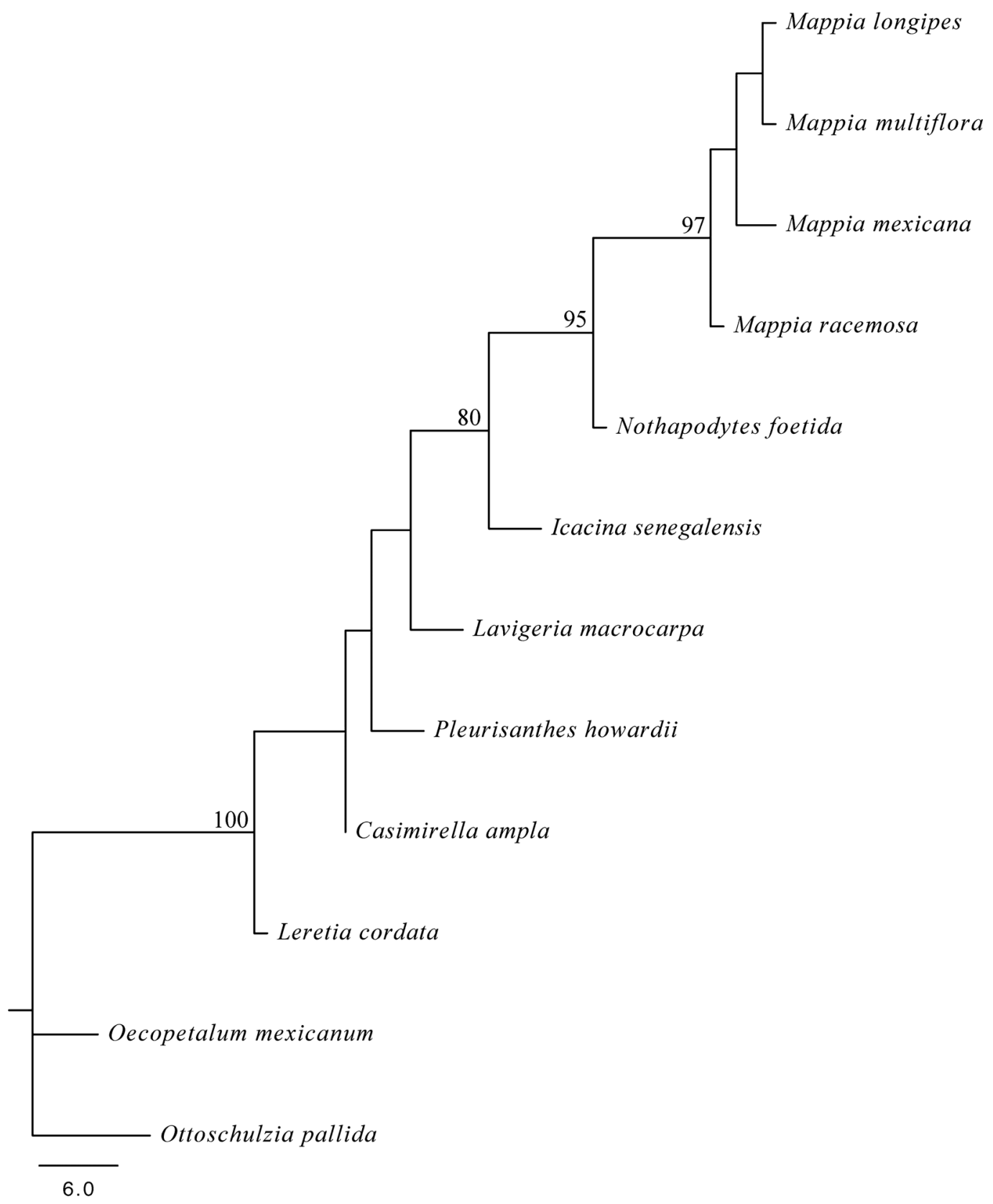

FIGURE 1. The single shortest tree (90 steps) recovered from the parsimony analysis of the morphological data. Bootstrap percentages are displayed for nodes that received at least 50 . 
In the molecular analyses, consistent relationships within Icacinaceae, or the Icacina group sensu Kårehed (2001), were recovered regardless of the optimality criterion. In both ML (Fig. 2) and parsimony analyses, Mappia was well supported (BP 98 for both) as sister (BP 100 for both) to Nothapodytes; this pair was sister to all other members of the Icacina group. Leretia cordata formed a strongly supported clade with Icacina and Lavigeria (ML BP or MBP 96, parsimony or PBP 92), with Alsodeiopsis Oliver in Bentham \& Hooker (1867: 996) being moderately supported as sister to this group (MBP 76, PBP 75). This clade (including Icacina, Lavigeria, Leretia, and Alsodeiopsis) received moderate support (MBP 75, PBP 75) as sister to the remaining members of Icacinaceae, i.e., Iodes, Phytocrene, Stachyanthus Engler (1897: 227) and Pyrenacantha Wight in Hooker (1830: 107). Within Mappia, M. mexicana received relatively weak support as sister to M. racemosa+ M. multiflora (MBP 72, PBP 61) in the bootstrap analyses; this same topology was recovered in the two shortest trees inferred from the parsimony analysis.

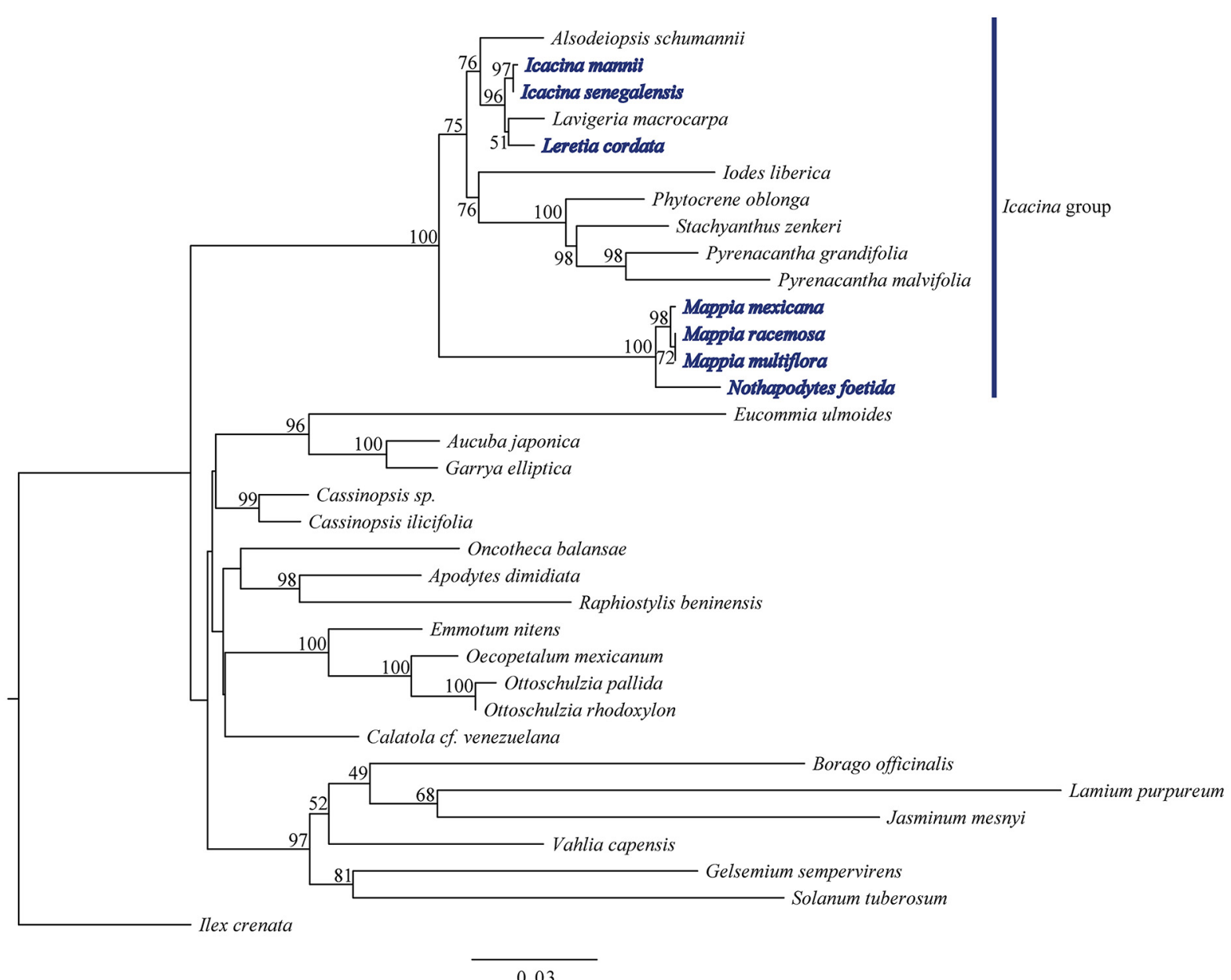

FIGURE 2. The best tree ( $\operatorname{lnL}$-8160.768319) from the ML analysis in RAxML (GTR+G) including support from the bootstrap. Only support of 50 percent and above is presented on the tree. The taxa previously included in the Mappia group are highlighted in blue.

In the combined molecular-morphological analyses, relationships recovered were generally similar to those inferred in the molecular analyses (Figure 3). Four most-parsimonious trees were recovered (1492 steps), differing only in the relationships within Mappia. In the four shortest trees recovered, Casimirella, Leretia, Pleurisanthes, Lavigeria, Icacina and Alsodeiopsis form a clade sister to Pyrenacantha, Stachyanthus, Phytocrene and Iodes, with Mappia+Nothapodytes sister to these two groups. In the bootstrap analysis of the combined data, relationships within Icacinaceae were largely unresolved, although Mappia received strong support as monophyletic (BP 98) and sister to Nothapodytes (BP 99), and within Mappia, M. longipes and M. multiflora were weakly supported as sister (BP 56). 


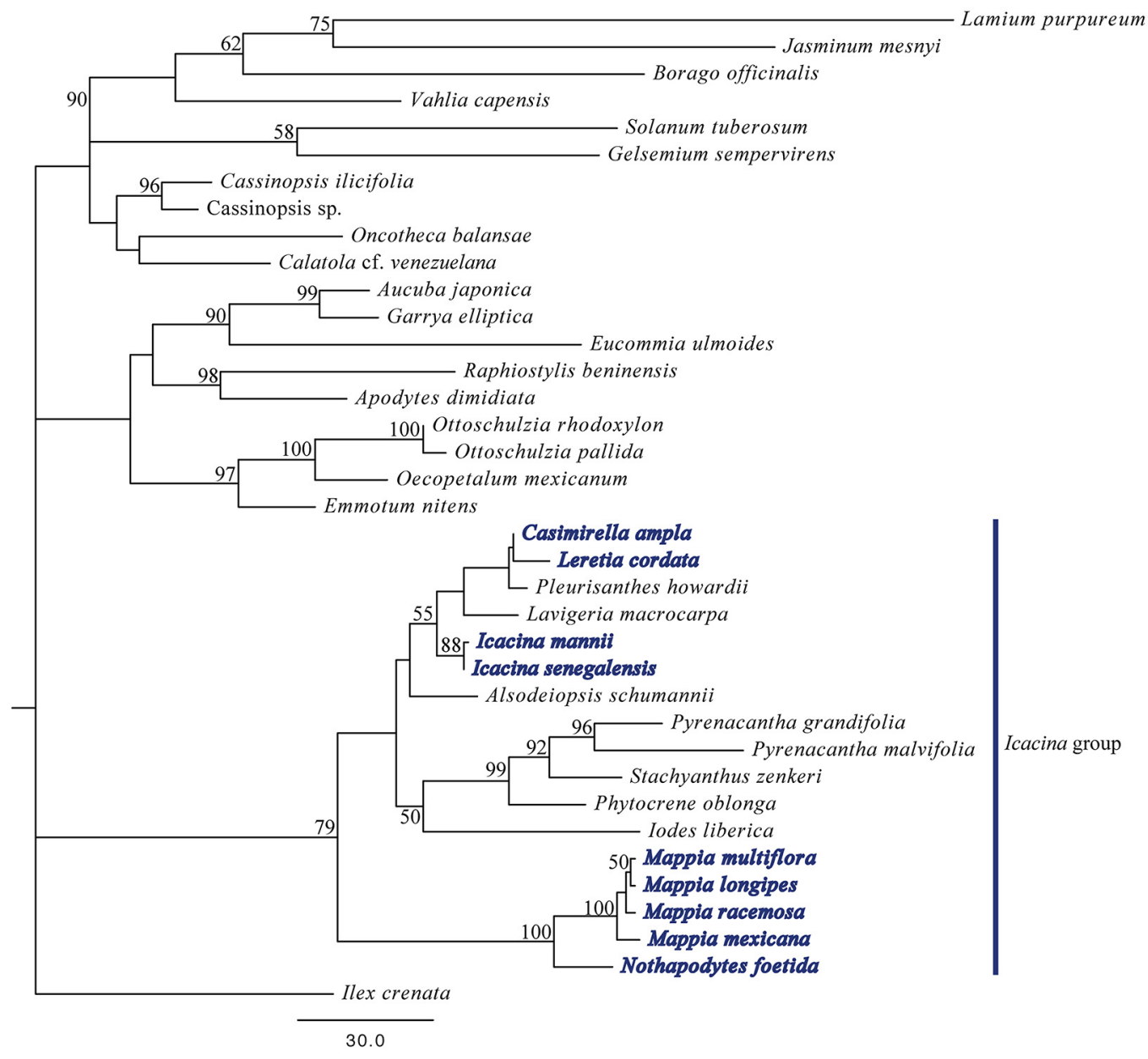

FIGURE 3. One of four most parsimonious trees (1492 steps) recovered from the combined molecular-morphological phylogenetic analysis. Bootstrap values are listed for nodes that received at least 50 percent support in the bootstrap analysis. Taxa previously included in the Mappia complex are highlighted in blue.

\section{Discussion}

Phylogenetic analyses based on morphological and molecular data indicate that Mappia is sister to the Asiatic genus Nothapodytes (Figs. 1, 2, 3), providing an example of a disjunction between the Neotropics and Southeast Asia. Given the abundant fossil record of Icacinaceae in Europe (Reid \& Chandler 1933, Collinson et al. 2012) and North America (Manchester 1994, Pigg et al. 2008, Rankin et al. 2008, Stull et al. 2011, 2012), this disjunction may reflect a broader historical distribution across Laurasia, perhaps during warmer periods during the Paleogene. Within Mappia, there is morphological support (Figure 1) for a continental clade (M. longipes, M. mexicana and M. multiflora) sister to the Antillean species M. racemosa; however, these relationships were not well resolved in the molecular analyses or in the combined molecularmorphological analyses. Seven morphological synapomorphies support monophyly of Mappia, but only one is considered relevant as a diagnostic for the genus: pollen with echinate ornamentation. However, this is also present in some other genera not included in morphological analysis (Dahl 1952), e.g., Discophora Miers (1852: 118), Desmostachys Miers (1852: 398) and Phytocrene. The floral disk is useful regionally for recognizing Mappia, but this character is also found in the African genus Icacina and the Asiatic genus Nothapodytes. 
Although Leretia cordata has historically been associated with Mappia, with some authors even considering these a single genus, the molecular analyses clearly indicate that they are not exclusively related. Leretia appears to form a clade with Casimirella, Pleurisanthes, Lavigeria and Icacina, which is more closely related to other icacinaceous genera (e.g., Alsodeiopsis, Iodes, and Phytocrene) than to the Mappia+Nothapodytes clade. Collectively, the molecular and morphological data provide strong support for the recognition of Mappia as distinct. The molecular data do not, however, provide sufficient support/ resolution within Mappia to discuss infrageneric relationships. A more extensive sampling of molecular data for the species of Mappia will be necessary to better understand the genus.

\section{Taxonomic Treatment}

Mappia Jacquin (1797: 22), nom. cons.

Type: Mappia racemosa Jacquin (1797: 22).

Shrubs or trees up to $25 \mathrm{~m}$ tall. Young branches cylindric, rarely slightly angular, in general all parts puberulent to sericeous-tomentose when young, becoming glabrous with time, hairs simple with two branches more or less the same length (i. e., malpighiaceous hairs). Leaves simple, alternate, exstipulate, membranaceous to subcoriaceous, sometimes clustered at the apex of a young branch, green when dry, rarely turning black; petiole up to $3 \mathrm{~cm}$ long, slightly sulcate, flattened, with a nitid abscission line in the base, puberulent to tomentose, especially in the grove; blades narrowly oblanceolate, narrowly obovate, elliptic to narrowly elliptic, puberulent on both sides, turning glabrous with time, with domatia in axils of secondary nerves, rarely absent, glabrous or puberulent abaxially, glabrous adaxially; apex acute or narrowly acuminate, sometimes emarginated; margin entire; base attenuate, rarely cuneate; venation penninerved, brochidodromous, main vein conspicuous abaxially, slightly sunken and conspicuous adaxially, 5-13 pairs of secondary nerves, alternate, conspicuous or not, tertiary venation perpendicular to the secondary nerves, conspicuous or not. Inflorescence up to $13 \mathrm{~cm}$ long, axillary, cymose, sometimes extensively branching, overall puberulent, sericeous-tomentose to strigose, peduncle up to $9.5 \mathrm{~cm}$ long, bracteate at the base of the peduncle, bracts up to $1.5 \mathrm{~mm}$ long, concave, triangular, sericeous-tomentose; without bracteoles. Flowers pentamerous, rarely tetra- or heptamerous, actinomorphic, hermaphroditic, articulate at the base. Calyx campanulate, slightly fleshy, puberulent or almost glabrous in the abaxial surface, lobes mucronate to deltoid. Corolla white-yellow, petals free, sericeous or glabrous outside, bearded inside, rarely glabrous; main vein inconspicuous, rarely conspicuous, apex acute, prolonged in a short tip, inflexed; margin slightly swollen apically, slightly papillate. Stamens alternate to petals, free; filament cylindrical, erect; anthers basifixed, dehiscent by longitudinal slits; connective narrowly triangular, prolonged with a short tip. Disk free, encircling base of the ovary, margin with 5 mucronate lobes, hirsute to glabrous outside, glabrous inside. Pistils subglobose, hirsute to glabrous, ovary unilocular, ovules two (only one developed), anatropous, pendent from the apex of the locule; style short; stigma capitate. Fruits subglobose or ellipsoidal drupes, glabrous, apex acute or apiculate; exocarp thin, red when mature; mesocarp slightly fleshy when mature; endocarp hard, smooth.

Distribution:-Greater Antilles, Mexico and parts of Central America (Guatemala, Belize, Nicaragua, Costa Rica and possibly Panama).

\section{Key to the species of Mappia}

1. Blades narrowly obovate, rarely elliptic, $5.0-10.5 \mathrm{~cm}$ long; apex obtuse to acute, sometimes prolonged in a short tip; 6-7 pairs of secondary nerves; petals glabrous; ovary glabrous..................................................... M. mexicana

- Blades narrowly elliptic, elliptic, narrowly oblong, obovate to oblanceolate, (5.0)10.0-29.5 cm long; apex narrowly acuminate to acute or rounded; 7-13 pairs of secondary nerves; flowers bearded inside; ovary pubescent .............. 2 
2. Inflorescence up to $12.5 \mathrm{~cm}$ long, peduncle up to $9.5 \mathrm{~cm}$ long; petals lightly bearded inside

- Inflorescence $2.0-8.5 \mathrm{~cm}$ long, peduncle up to $4 \mathrm{~cm}$ long; petals heavily bearded inside

3. Blades 7.0-29.5 cm long; venation conspicuous abaxially, turning dark green when dry................ M. multiflora

Blades 4.5-18.0 cm long; venation inconspicuous abaxially, turning brown when dry M. racemosa

1. Mappia longipes Lundell (1942: 26). Fig. 4.

Type:-MÉXICO. Chiapas: Nuevo Amatenango, 1300 m, July 17, 1941, Matuda 4798 (holotype MICH!, isotypes A!, NY!, F, TEX/LL).

Shrubs. Leaves membranaceous, turning black when dry; petioles $15-25 \mathrm{~mm}$ long, slightly sulcate, flattened, slightly tomentose or puberulent; blades narrowly oblanceolate, 9.7-20.0 53.0-5.0 cm; puberulent abaxially, turning glabrous, minute domatia in the axils of secondary nerves; apex acute; margin entire; base attenuate; 9-12 pairs of secondary nerves, conspicuous. Inflorescence axillary, 11.0-12.5 cm long, cyme, branching extensively, sericeous-tomentose; peduncle up to $9 \mathrm{~cm} \mathrm{long}$, bracts on the base of the peduncle, rarely along it, up to $1.5 \mathrm{~mm}$ long, ovate, sericeous-tomentose outside; apex acute; margin entire; pedicel up to $2 \mathrm{~mm}$ long, sericeous-tomentose. Calyx campanulate, puberulent outside, glabrous inside, lobes mucronate; apex acute; margin entire. Corolla white, petals narrowly oblong, 5.0-5.5 5 1.0-1.2 mm, glabrous outside, slightly bearded inside; apex slightly acute, inflexed; margin entire. Stamens $4.0-4.5 \mathrm{~mm}$ long, filament $3.0 \mathrm{~mm}$ long; anthers $1.0 \mathrm{~mm}$ long; connective linearly triangular, prolonged in a small tip. Disc with 5 mucronate lobes, glabrous on both surfaces. Pistil subglobose, $3 \mathrm{~mm}$ high, hirsute; style $0.5 \mathrm{~mm}$ long, glabrous; stigma capitate, slightly papillose. Fruit unknown.

Material examined:- only known from the type specimen.

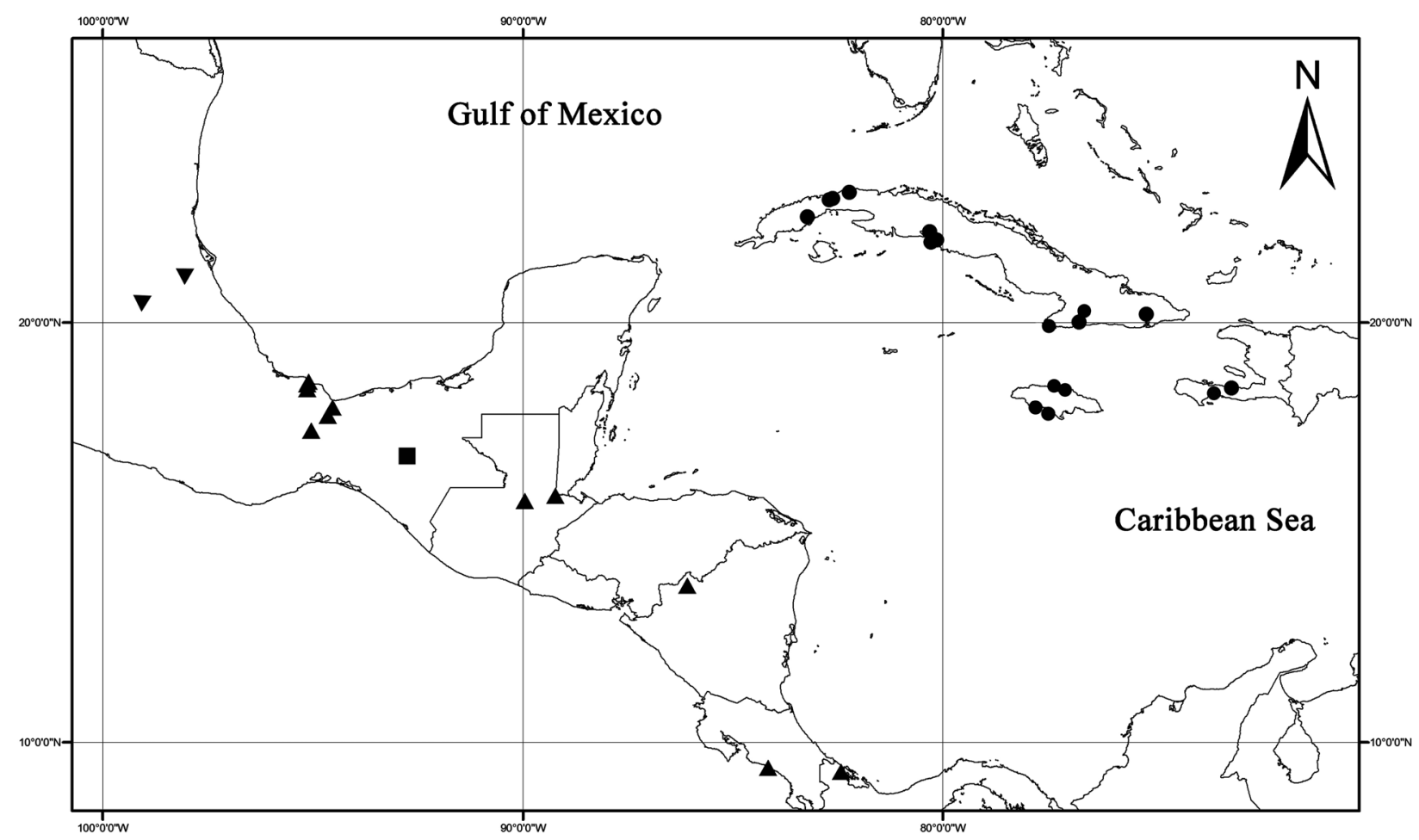

FIGURE 4. Distribution map of the genus Mappia. Mappia longipes $(\bullet)$.

Diagnostic features:-Mappia longipes is similar to M. multiflora but with a long peduncle up to $9 \mathrm{~cm}$ long (vs. $3 \mathrm{~cm}$ ). The phylogenetic analysis based on morphology shows $M$. longipes to be sister to $M$. mexicana plus M. multiflora. The species is only known from the type specimen, and morphological variation 
of inflorescences therefore cannot be evaluated. Additional collections of Mappia in Chiapas will be necessary to determine if $M$. longipes is a distinct species or instead conspecific with M. multiflora.

Distribution and ecology:-Only known from the type locality in Mexico (Chiapas); it grows in forests at $1300 \mathrm{~m}$.

Conservation Status:-DD; there is inadequate information to make a direct, or indirect, assessment of its risk of extinction based on its distribution and/or population status.

Common Names:- unknown. No uses reported.

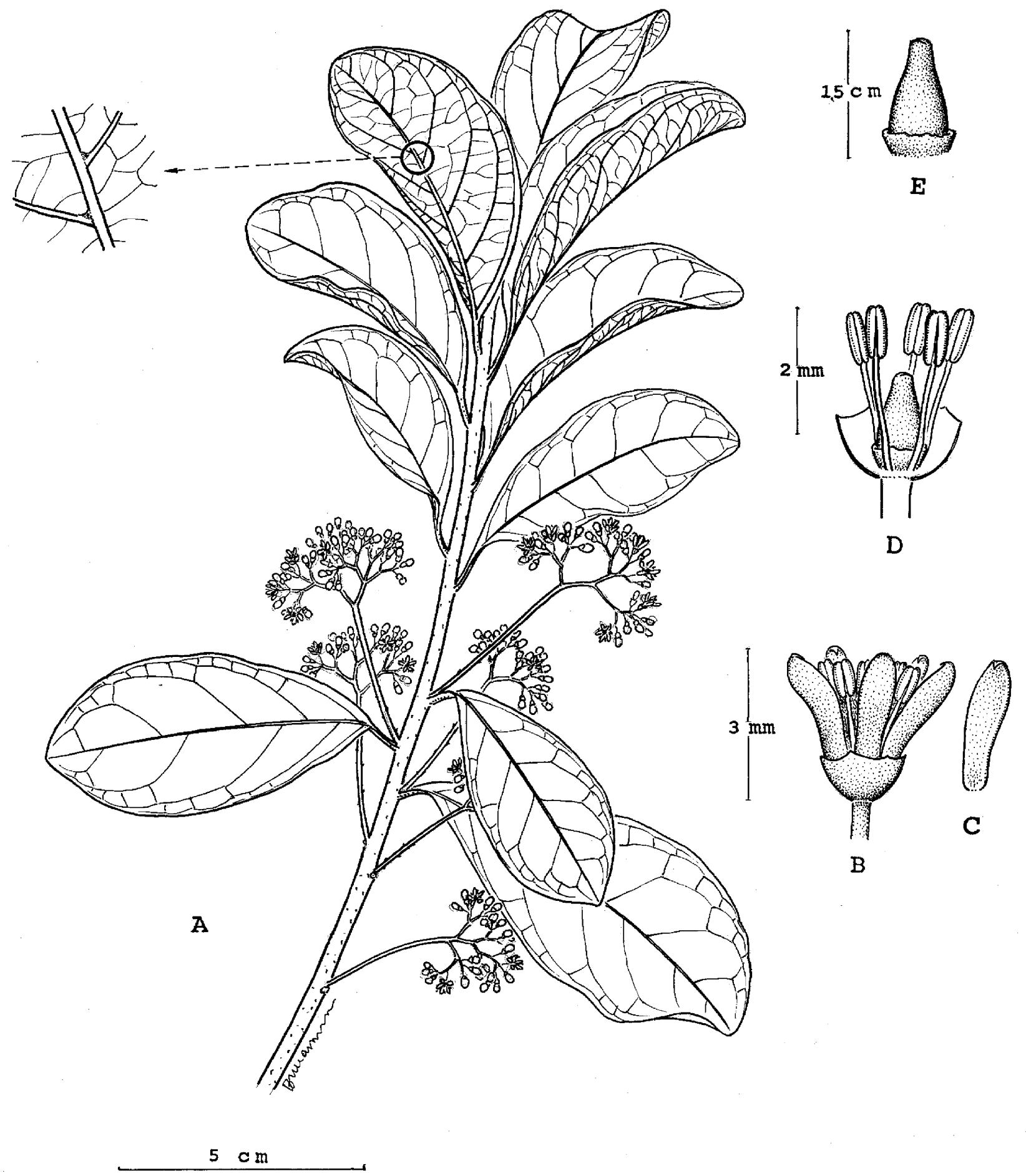

FIGURE 5. Mappia mexicana. A. Flowering branch and detail of a domatium in the abaxial surface of the leaves. B. Flower. C. Inside of petal. D. Floral dissection (petals removed) showing androecium and gynoecium. E. Gynoecium with ovary, minute style and disk. 
2. Mappia mexicana Robinson \& Greenman (1895: 150). Figs. 4 \& 5.

Type:-MÉXICO. San Luis Potosí: lowlands about Micos, 8 December 1891, Pringle 5494 probably in error [5094] (holotype GH!, isotype: A!).

Homotypic synonyms: Leretia mexicana (B.L.Rob. \& Greenm.) Sleumer (1940: 245).

Shubs to trees up to $10 \mathrm{~m}$ tall. Leaves menbranaceous, green when dry; petioles 3-13 mm long, slightly sulcate, slightly flattened, puberulent, especially in the groove; blades obovate, rarely elliptic, 4.5-9.7 (11.5) 5 $1.9-4.3 \mathrm{~cm}$; glabrous on both surfaces, domatia in axils of secondary nerves; apex obtuse or acute, sometimes a short point; margin entire; base attenuate; 6-7 pairs of secondary nerves, conspicuous or slightly conspicuous. Inflorescence axillary, $1.2-5.3 \mathrm{~cm}$ long, cymes, sometimes extensively branching, all puberulent; peduncle up to $3 \mathrm{~cm}$ long, one pair of bracts at the base of the peduncle, rarely along it, $1 \mathrm{~mm}$ long, narrowly ovate to ovate, sericeous-tomentose; apex acute; margin entire; pedicel up to $2.5 \mathrm{~mm}$ long, puberulent. Calyx campanulate, minutely puberulent or glabrous outside, lobes mucronate or slightly deltoid; apex acute; margin entire. Corolla white, petals oblanceolate, 2-3 $\mathrm{mm} 51 \mathrm{~mm}$, glabrous on both sides; apex slightly acute, inflexed; margin slightly swelled to the apex, more or less papillose. Stamens 2-3 mm long, filament 1-2 mm long; anther $1 \mathrm{~mm}$ long; connective slightly triangular, prolonged into a point. Disk with 5 mucronate lobes, glabrous on both surfaces. Pistil subglobose, $1.5 \mathrm{~mm}$ high, glabrous; style $0.5 \mathrm{~mm}$ long, glabrous; stigma capitate. Fruits unknown.

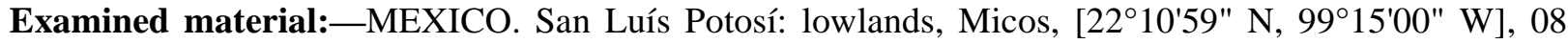
Dec 1891 (fl.), Pringle 5094 (A, GH, TEX/LL). Tamaulipas: entre Torrecillas y Pénjamo, [238'59"N, 98 22'0"W], 500-600 m, 30 May 1974, González-Medrano 7265 (MEXU-2); vicinity of Tampico,

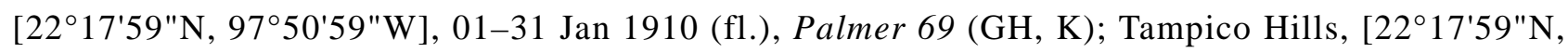
9750'59"W], 16 Jun 1897 (fl.), Pringle 6645 (ENCA, F, K-2, GH, MEXU-2, K, NY, P-2).

Diagnostic features:-Mappia mexicana is the most remarkable species of genus with small obovate leaves and petals lacking the typical beard inside. In the phylogenetic analysis based on morphology, this species is placed in the continental clade with M. longipes and M. multiflora.

Distribution and ecology:-Mappia mexicana is endemic to the Gulf slope of Mexico, in a small area between the borders of the states of San Luis Potosi and Tamaulipas. It grows in deciduous forest in calcareous soil from 100-600 m.

Conservation Status:-EN. Mappia mexicana meets the criterion B1ab of the IUCN. The area occupied by $M$. mexicana is less than $5.000 \mathrm{~km}^{2}$, and it is only known from three localities including some historical collections in the city of Tampico. The habitat of the species is highly fragmented under natural conditions and is also severely threatened by anthropogenic activities. None of the known populations resides in an area under any level of protection.

Common Names:- unknown. No uses reported.

\section{Mappia multiflora Lundell (1970: 139). Fig. 4 \& 6.}

Type:-BELIZE. Toledo District: on high ridge, on hill slopes, Sulphur Hill, Edwards Road beyond Columbia, Jan. 15, 1948, Gentle 6365 (holotype LL!, isotype K!, NY!).

Trees up to 15-20(-25) $\mathrm{m}$ tall. Leaves membranaceous, turning dark green when dry; petioles 10-35 mm long, slightly sulcate, flattened, tomentose or puberulent, especially when young, becoming glabrous with time; blades narrowly oblong, narrowly obovate, 7.0-29.5 $52.4-7.4 \mathrm{~cm}$; slightly puberulent abaxially, glabrous with time, minute domatia in axils of secondary nerves; apex narrowly acuminate; margin entire; base attenuate, 7-13 pairs of secondary nerves, alternate, conspicuous. Inflorescence axillary, 2.0-8.5 cm long, cymose, sometimes branching extensively, overall tomentose; peduncle up to $3 \mathrm{~cm}$ long, one pair of bracts in the base of the peduncle, rarely along it, $1.5 \mathrm{~mm}$ long, ovate, sericeous-tomentose outside; apex obtuse; margin ciliate; pedicel up to $2.0 \mathrm{~mm}$ long, sericeous-tomentose. Calyx campanulate, puberulent 
outside, glabrous inside surface, lobes conspicuous, mucronate, up to $2 \mathrm{~mm}$ long; apex acute; margin entire. Corolla white, petals narrowly oblong, narrowly obovate or narrowly ovate, 3.0-4.5 5 1.0-1.2 mm, sericeoustomentose outside, rarely almost glabrous, bearded inside, sometimes only in the abaxial area; apex acute, inflexed; margin entire. Stamens 2-3 mm long; filament $2 \mathrm{~mm}$ long; anther $1 \mathrm{~mm}$ long; connective slightly triangular, prolonged in a short tip. Disc with 5 mucronate lobes, hirsute to glabrous on abaxial surface, glabrous on the adaxial surface. Pistil subglobose, 2.3-2.5 mm long, densely hirsute; style $0.5 \mathrm{~mm}$ long, glabrous; stigma bilobate or capitate. Fruit globose or ellipsoidal, apex acuminate, base rounded, 14-26 5 10$20 \mathrm{~mm}, 10-13 \mathrm{~mm}$ thick; endocarp slightly rugose.

Material examined:-GUATEMALA. Alta Verapaz: along road between Chajmayic and Sebol, [15 ${ }^{\circ} 45^{\prime}$ 48’N, 8956'-57"W], 18 Apr 1942, Steyermark 45736 (F). Izabal: Cadenas, on bank of Río Gracias, 22 Feb 1975, Contreras 19026 (LL/TEX); Cadenas: bordering Rió Gracias, about 4 km. north [1552’60"N, 89¹3’0"W], 22 Feb 1975, Contreras 19027 (LL/TEX). Petén: 18 Mar 1967, Contreras 6781 (LL/TEX). MEXICO. Veracruz: $13 \mathrm{~km} \mathrm{~N}$ de Catemaco, en el ejido de la Perla de San Martín, Catemaco, [18 25'00"N, 95 07'00"W], 14 Jun 1972 (fr), Beaman 6174 (F, MEXU, MO, LL/TEX, XAL, TEX); Estación Biológica Tropical los Tuxtlas, [18²6’60"N, 95¹3’0"W], Calzada 97 (F, MEXU); Estación Biológica Tropical los Tuxtlas, [18²6’60"N, 95¹3'0"W], 3 Apr 1974 (fr.), Calzada 1211 (ENCA, MEXU, ME, MO, XAL); Río Máquinas, camino a la Colonia Ruíz Cortinez, [20³6'0"N, 99¹8'0"W], 18 May 1985 (fr.), Cedillo 3225 (MEXU); a 34 km de Tantoyuca, hacia Tuxpan, 11 Dic 1970 (vg.), Chiang 304 (MEXU); km 0-2 del camino plan de Arroyo-Alvaro Obregón, [1746’60”N, 94³7’60”W], 130-150 m, 15 Apr 1974 (fr.), Dorante 2866 (F, MEXU-2, XAL); Estación Biológica Tropical los Tuxtlas, [18²6’60"N, 95¹3’0"W], 17 Apr 1982 (fr),

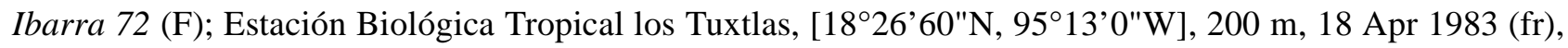
Ibarra 534 (ENCA, MEXU, MEXU-2, TUXTLAS, MO, NY); Estación Biológica Tropical los Tuxtlas, [18²6’60"N, 95²1'0"W], 200 m, 12 Feb 1984 (fl.), Ibarra \& Sinaca 1246 (ENCA, MEXU-TUXTLAS, XAL); Estación Biológica Tropical los Tuxtlas; camino Laguna Escondida $1.5 \mathrm{~km} \mathrm{NO}$, [18²6’60"N, 95¹3'0"W], 160 m, 17 Feb 1984 (fl.), Ibarra et al. 1288 (ENCA, MEXU-2, MEXU-TUXTLAS-2); Lote 71,

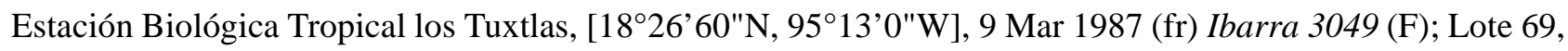
Estación Biológica Tropical Los Tuxtlas, [18²6’60"N, 95¹3’0"W], 300 m, 18 Jan 1990 (fl.), Ibarra \& Sinaca Colín 3472 (XAL, MEXU, P); campamento Hnos. Cedillo a 6 km al N por el poblado N 5, [18 25'30'N, 9507'-09'W] 150 m, 14 Mar 1975 (fr.), Ortiz \& Martiniano 25 (F, MEXU-2, XAL); 3 km al NE del campamento Cedillo camino a la laguna, 18 Mar 1974 (fr), Ponce 220 (F, XAL, MEXU); Estación Biológica Tropical los Tuxtlas, [18²6’60"N, 95¹3’0"W], 250 m, 4 Feb 1986 (fl.), Sinaca 423 (MEXU-2, MEXUTUXTLAS-2, MO, XAL); Estación Biológica Tropical los Tuxtlas, [18²6’60"N, 95¹3’0"W] 4 Feb 1986 (fl.), Sinaca 1986 (ENCA); brecha Hnos. Cedillo-La Escuadra, [1746’60”N, 94³7’60”'W] 27 Feb 1974 (fr.), Vázquez 45 (F, NY); Rió Soloxuchil, a orillas del campamento Hnos. Cedillo, [1746’60’N, 94³7'60”W], 29 Mar 1974, (fr.), Vázquez 129 (F, MEXU, XAL); 5 km SE de la Escuadra, 150 m, 15 Jan 1975 (fl.), Vázquez

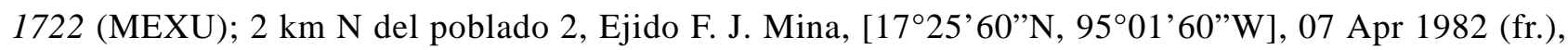
Vázquez et al. 2385 (ENCA, F, CAS, MO, MEXU, TEX/LL, XAL, TEX); $2 \mathrm{~km} \mathrm{~N}$ del poblado 2, ejido F. J. Mina, [17²5'60'N, 9501'60'W], 10 Apr 1982, Vázquez V-2405 (CAS, MEXU, MO, TEX); 2 km N del poblado 2, Ejido F. J. Mina, [17²5'60”N, 9501'60”W], 13 Apr 1982, Vázquez T. M. V-2446 (CAS, MEXU, MO, TEX); $600 \mathrm{~m}$ al NO de la Ebitrolotu por el camino a Laguna Escondida, 5 Apr 1973 (fr.), Villegas 80 (BM, ENCA, F, K, MEXU, XAL); $13.7 \mathrm{~km}$ al E de la Laguna, sobre terracería a Uxpanapa, [1758'60"N, 94³1'0”'W], 5 Mar 1981, Wendt et al. 2996 (CAS, NY, XAL, MO, TEX/LL, MEXU); $13.7 \mathrm{~km}$ al E de la

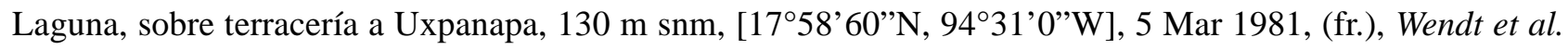
2996A (ENCA-2, MICH, NY, MEXU, TEX/LL, XAL); vivero hule al N de campamento la Laguna,

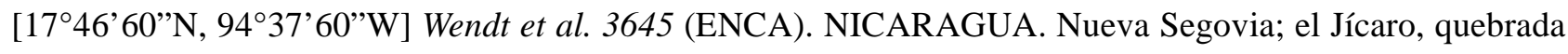
de Tranquera [134ㄴ'N, 8604'W], 26 Dec 1981, Moreno 13718 (MO). COSTA RICA: Puntarenas, Cantón de

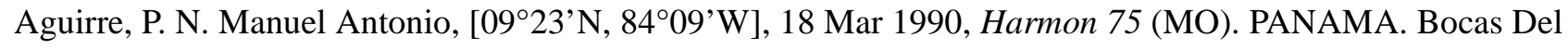

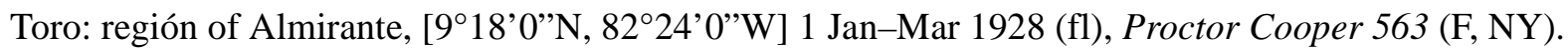


Diagnostic features:-Mappia multiflora is similar to M. longipes but with a shorter peduncle up to $3 \mathrm{~cm}$ long (vs. $9 \mathrm{~cm}$ ). Its leaves are also longer than those of $M$. racemosa. The morphological analysis also shows M. mutiflora as sister to $M$. longipes plus M. mexicana. It was considered informally as synonymous with $M$. racemosa, but Angulo et al. (in press) proposed to keep both as distinct species based on morphology and niche modeling.

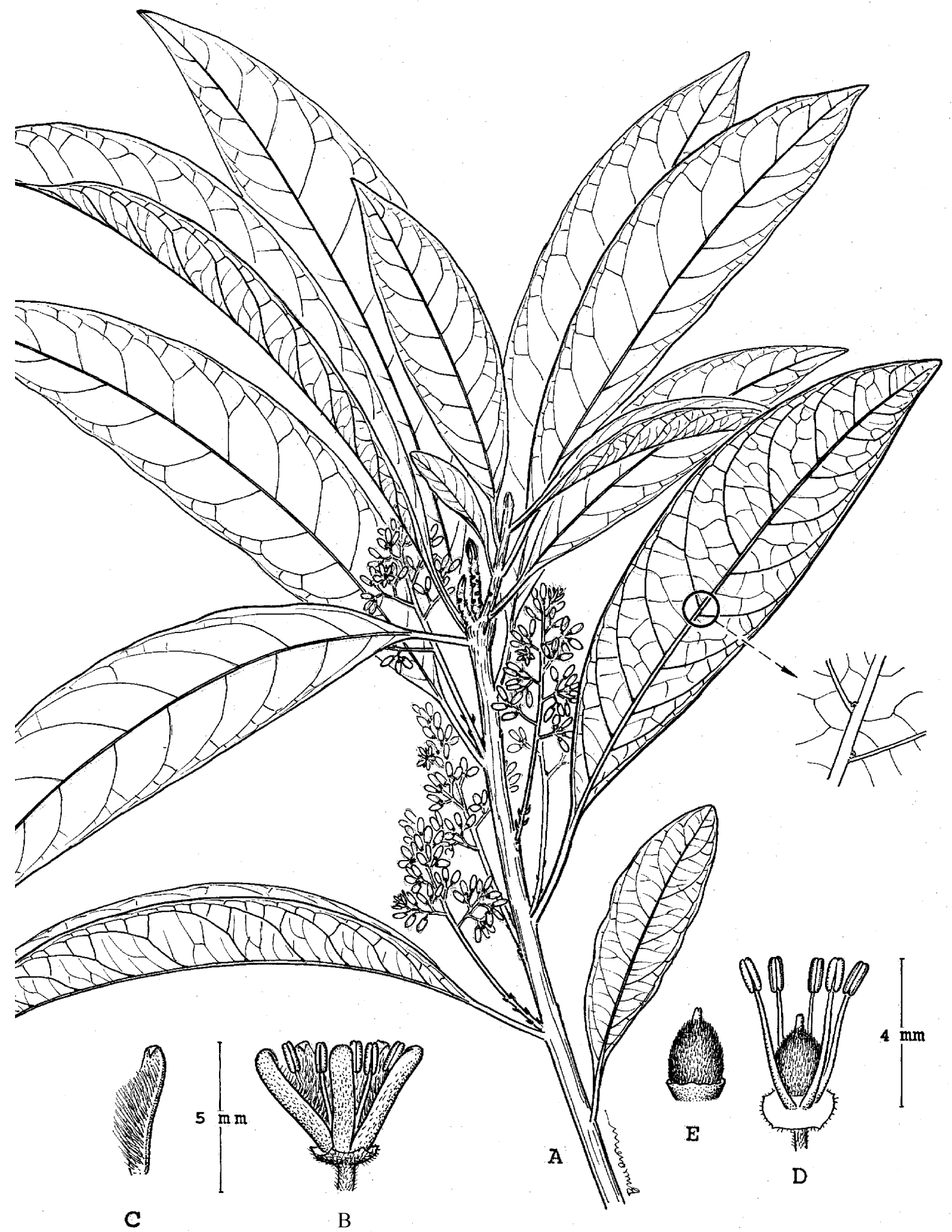

FIGURE 6. Mappia multiflora. A. Flowering branch and detail of domatia in the abaxial surface of leaves. B. Flower. C. Inside of petal. D. Floral dissection (petals removed) showing androecium and gynoecium. E. Gynoecium showing ovary, minute style and disk. 
Distribution and ecology:-Mexico (Veracruz), Belize, Guatemala, Nicaragua, Costa Rica and Panama; in evergreen to deciduous forest on calcareous but also serpentine soil, 100-500 m.

Conservation Status:-LC. Collections of Mappia multiflora are scattered over a large area (from México to Panama), including some areas that are protected. It is therefore listed as least concern (LC) according to IUCN Red List criteria (IUCN 2001).

Common Names:-unknown. No uses reported.

\subsection{Mappia racemosa Jacquin (1797: 1: 22). Fig. 4.}

Type:-none indicated; lectotype Jacquin, Hort. Schoenb. t 47, designated by Howard (1976).

Homotypic synonyms:-Leretia racemosa (Jacquin) House (1922: 61).

Heterotypic synonyms:-Icacina dubia Macfadyen (1837: 122). Type: JAMAICA. Port-Royal and St. David's Mountains (holotype K!).

Mappia affinis Miers (1852: 395). Type: JAMAICA. Manchester: Ins. Jamaicae, in herb. Hook. (Purdie) (holotype K!). Mappia racemosa var. typica Howard (1942: 64) nom. illeg.

Mappia racemosa Jacquin var. brachycarpa Grisebach (1866: 119). Mappia racemosa subsp. brachycarpa (Grisebach) Borhidi (1983: 185). Syntypes: [CUBA]: Wright 1389 (GH, K-2, MA, MO-2, NY-2, P-3), 1578 (GH!, GOET!, HAC!, K!, MA!, MO-2!). Type: [Wright 1587] (lectotype designated Duno et al. 2007, GOET!; isotypes, GH!, HAC!, K!, MA!, MO-2!).

Mappia angustifolia Grisebach (1866: 119). Type: "[Cuba] Wright [2638], in Cuba Orientali, prope" (lectotype, designated Duno et al. 2007, GOET; isotype: G!, GH!, HAC!, K!, MA!, MO!).

Shrubs or trees up to 10-20(-25) m high. Leaves membranaceous, sometimes clustered at the apex of branches, pale green when dry; petiole 5-28 mm long, slightly sulcate, flattened, slightly tomentose or puberulent, especially in the grooves; blades narrowly obovate, narrowly oblong, narrowly elliptic or elliptic, 4.5-18.0 5(1.5) 2.0-6.2 cm; puberulent abaxially, turning glabrous with time, minute domatia in the axil of secondary nerves, sometimes absent; apex acute to narrowly acuminate, rarely rounded; margin entire; base attenuate; 7-13 pairs of secondary nerves, alternate, conspicuous or not. Inflorescence axillary, 3.0-7.5 cm long, cymose, sometimes extensively branching, overall sericeous-tomentose; peduncles up to $3 \mathrm{~cm}$ long, sericeous-tomentose, one pair of bracts in the base peduncle, rarely along it; $1.5 \mathrm{~mm}$ long, ovate, sericeoustomentose; apex obtuse; margin ciliate; pedicel up to $2.0 \mathrm{~mm}$ long, sericeous-tomentose. Calyx campanulate, puberulent to pilose abaxially, lobes conspicuous, mucronate or deltoid, up to $3 \mathrm{~mm}$ long; apex acute; margin entire. Corolla white, petals narrowly oblong, narrowly obovate or narrowly ovate, 3.5-4.5 $51.0 \mathrm{~mm}$, sericeous-tomentose abaxially, rarely glabrous, bearded inside, sometimes only basally; apex acute, inflexed; margin entire. Stamens 2.5-4.5 mm long, filament 2.0-3.5 mm long; anthers $1.0 \mathrm{~mm}$ long; connective triangular, prolonged into a tip. Disc with five mucronate lobes, hirsute or glabrous outside, glabrous inside. Pistil subglobose, $1.8-2.0 \mathrm{~mm}$ high; hirsute, rarely glabrous; style $0.5 \mathrm{~mm}$ long, glabrous; stigma bilobulate or capitate. Fruit globose or ellipsoidal, rugose, $1.0-2.350 .8-1.1 \mathrm{~cm}, 0.6-1.3 \mathrm{~cm}$ in diameter.

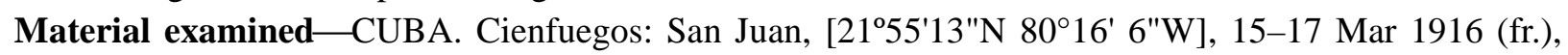
Britton et al. 15459 (F, NY); Guabairo, Soledad, [22¹0'0"N, 80¹7'60"W], 15 Dec 1928, Jack 6902 (A-2, F, K, NY). La Habana: Guanajay mr. [22 ${ }^{\circ} 55^{\prime} 32^{\prime \prime N}, 82^{\circ} 41^{\prime 22}$ "W], 11 Dec 1904 (fr.), Baker y Van Herman 4265

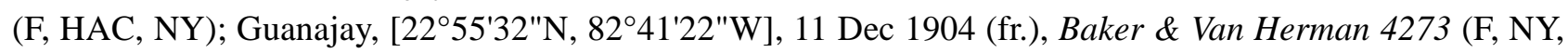
P); Bayate, Monte Oscuro, [20¹7'59"N, 76 35'0"W], 17 Jul 1915, Ekman 6238 (F, NY); Papayo (of the

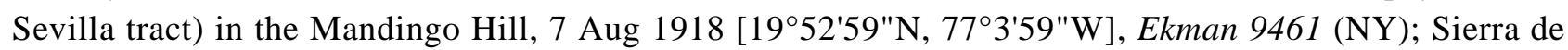
Anafe, near Caimito, [22 ${ }^{\circ} 52^{\prime} 00^{\prime \prime N}, 82^{\circ} 20^{\prime} 00^{\prime \prime W}$ ], 17 Nov 1921 (fr), Ekman 13492 (F, MICH, NY); cresta de la Sierra de Anafe, 10 Oct 1956, Hno. Alain 6013 (GH, HAC); Sierra de Anafe, [22 $\left.{ }^{\circ} 57^{\prime} 0^{\prime \prime} \mathrm{N}, 76^{\circ} 45^{\prime} 0^{\prime \prime} \mathrm{W}\right], 14$ Dec 1911, Hno. León 2829 (HAC); Sierra de Anafe, [2257'0"N, 7645'0"W], 27 Dec 1911, Hno. León 2849

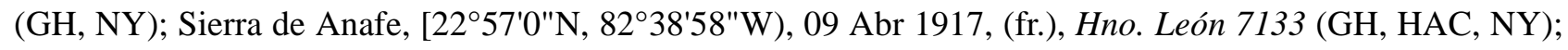

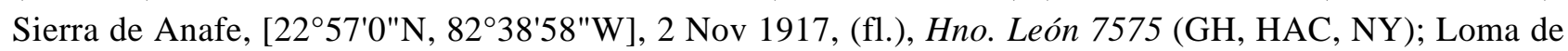
Somorrostro, Jamaica, 13 Jul 1923, Hno. León R. 11455 (A, NY); Sierra Mendoza, [2245'0"N 82¹3'59"W], 
25 Dec 1911, Shafer 11130 (A, GH, K, NY); Guanajay, San Grabiel, [2255'32"N, 8241'22"W], 11 Nov 1904, (fr.), Van Hermann 250 (F, K, MO, NY); Setes de Managua, 04 Sep 1904, Van Herman 1294 (F, HAC); Sierra de Anafe Rocky Hillside, [22 $57^{\prime} 0 " N$, 82³8'58"W], 23 Dec 1911, Wilson 11496 (F, MO, NY-2); Sierra de Anafe, [22 $\left.{ }^{\circ} 7^{\prime} 0 " \mathrm{~N}, 8^{\circ} 38^{\prime} 58^{\prime \prime} \mathrm{W}\right], 27$ Dec 1911, Wilson \& Hno. León 11547 (NY); Valley of Río

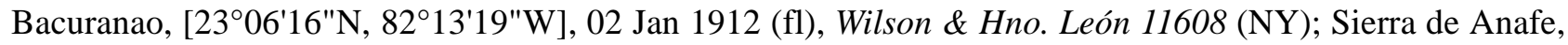

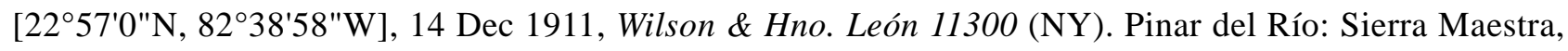
manacal (prope Sevilla), [22 $30^{\prime} 59^{\prime \prime N}, 83^{\circ} 13^{\prime} 0^{\prime \prime W}$ ], 17 Jul 1918, Ekman, E. L. 9408 (NY); Sierra Maestra, El Gigante, [200'59"N, 7645'0"W], 04 Jan 1923, Ekman, E. L. 16074 (F, K, NY); Sierra Maestra, [200'59"N, 77³'0"W], 01 Jul 1922, (fr.), Hno. León 10981 (HAC, NY). Villa Clara: Buenos Aires, Trinidad Hills, 05 Mar 1929, Jack, J. G. 6979 (A, NY); Buenos Aires, Trinidad Hills, 11 Abr 1929, Jack, J. G. 7233 (A); Buenos Aires, Trinidad Hills, 24 Jul 1930, Jack, J. G. 8068 (A, F, MO, NY); Without exact locality, Farallones de La Perla, 14 Feb 1911, Shafer, J. A. 8770 (A, NY-2); without exact locality, Wright 1389 (GH, K-2, MA, MO-2, NY-2); without exact locality, Wright 1578* (GH, K, MA, MO-2). HAITI. Massif de la Hotte: 28 Jan 1928, Ekman 9535 (K, NY); Massif de la Hotte (part. este), sobre Morne Rochelois; 2.8 km oeste de Miragoane y $22.4 \mathrm{~km}$ sur en la carretera a Paillat y Las minas de Reynolds Haitian Rochelois, 25 Jan 1984, Zanoni et al. 28664 (NY). JAMAICA. Manchester: Herron Hill, 10 Jan 1960, Howard 15021 (A); upper slopes and summit of Herons (Shooters or Martine), 17 Mar 1958, Proctor 17475 (A, MO, NY); without exact locality: Grien

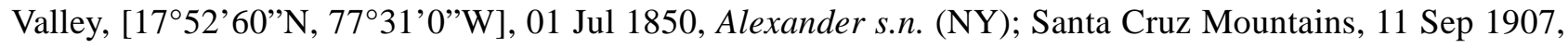
Britton 1304 (NY); without exact locality, 27 Jan 1898 (fl), Egger 3789 (MEXU, MO, TEX/LL); Great Valley,

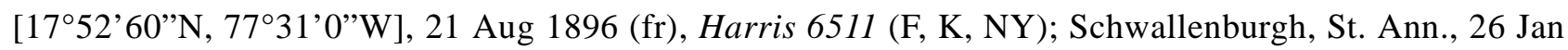
1898, Harris 7043 (A-2, K, GH, NY); Peckam, Woods Upper Claredendon, 27 Sep 1912, Harris 11193 (K, NY); without exact locality, Wright 1578 (GH, K, MA, MO-2). PUERTO RICO. Without exact locality, 16 Feb 1932, Britton \& Britton 9911 (NY).

Nomenclatural notes:-The infraspecific taxa have been treated as varieties or subspecies (Baehni 1936, Howard 1942, Liogier 1953, Borhidi 1983). Howard (1942) mentioned some characters for each subspecific taxon, but they do not consistently exhibit them. The most important difference, fruit with a fleshy mesocarp or not, also occurs in Central America in specimens from the same localities (Los Tuxtlas Biological station), and therefore the difference is probably due to variation in maturity of the fruit. The Flora of Cuba did not recognize both varieties (Duno \& Angulo 2010), and some nomenclatural clarification was carried out by Duno et al. (2007).

Diagnostic features:-See comments under M. multiflora.

Distribution and ecology:-Mappia racemosa grows in the Greater Antilles in evergreen and deciduous forest in calcareous soil at $0-1100 \mathrm{~m}$. It flowers and fruits continuously.

Conservation Status:-LC. Mappia mexicana is found in the Greater Antilles scattered over a large area, including some areas that are protected. It is therefore listed as least concern (LC) according to IUCN Red List criteria (IUCN 2001).

Common Names:-Palo de caña (Bisse 1988). No uses reported.

\section{Acknowledgments}

The second author thanks Santiago Castroviejo and Mauricio Velayos (MA), who helped obtain loan material for this study; the curators of the following herbaria: BM, CICY, F, G, GOET, HUH, K, MEXU, MO, NY, P, TX, US, XAL, and VEN, and the Kew Latin American Research Fellowships program for providing funding to visit $\mathrm{K}$ and $\mathrm{BM}$ to study the type material. At CICY, to Lilia Lorena Can, Amilcar Castillo and Silvia Hernández. The third author (GWS) acknowledges support from NSF grant 0743457, and thanks Peter Jørgensen (MO), Alfredo Fuentes, and Pablo Soliz (LPB) for assistance with field work in Bolivia. Helpful comments were provided by Jesper Kårehed. 


\section{References}

Angulo, D.F. (2006) Análisis filogenético y sistemática del género Mappia (Icacinaceae) en el Neotrópico a partir de caracteres morfo-anatómicos (bachelor thesis). Instituto Tecnológico de Conkal, Yucatán, 75 pp.

Baehni, C. (1936) Revision des genres Neoleretia, Mappia et Humirianthera. Candollea 7: 167-184, plate IV.

Baillon, H.E. (1874) Deuxième étude sur les Mappiées. Adansonia 11: 187-203.

Bentham, G. (1862) Olacineae. In Bentham, G. \& Hooker, J. D. (eds.), Genera plantarum, vol. I, part 1. Reeve, London, pp. $342-355$.

Bisse, J. (1988) Árboles de Cuba. Editorial Científico Técnica, La Habana. 384 pp.

Blume, C.L. (1825) Bijdragen tot de flora van Nederlandsch Indië. Lands Drukkerij, Batavia, 288 pp.

Blume, C.L. (1850) Museum Botanicum Lugduno-Batavum sive stirpium exoticarum novarum vel minus cognitarum ex vivis aut siccis brevis expositio et descriptio 1, pp. 209-224.

Borhidi, A.L. (1983) New names and new species in the flora of Cuba and Antilles III. Acta Botanica Hungarica 29: $181-215$.

Collinson, M., Manchester, S. \& Wilde, V. (2012) Fruits and seeds of the Middle Eocene Messel biota, Germany. In: Abhandlungen der Senckenberg Gesellschaft für Naturforschung, pp. 27-31.

Dahl, O. (1952) The comparative morphology of the Icacinaceae, VI. The pollen. Journal of the Arnold Arboretum 33: 252252.

de Candolle, A. P. (1836) Prodromus systematis naturalis regni vegetabilis 5. Mason \& Sons, Paris, 706 pp.

Doyle, J.J. \& Doyle, J.L. (1987) A rapid DNA isolation procedure for small quantities of fresh leaf tissue. Phytochemical Bulletin 19: 11-15.

Duno de Stefano, R., Angulo, D.F. \& Stauffer, F. (2007) Emmotum harleyi, a new species from Bahia, Brazil and lectotypification of other Icacinaceae. Novon 17: 306-309.

Duno de Stefano, R. \& Angulo Pérez D.F. (2010) Icacinaceae. In: Greuter, W. \& Rankin Rodríguez, R. (eds.). Flora de la República de Cuba, serie A, plantas vasculares, fascículo 16 (4). Gantner Ruggell, Liechtenstein, pp 3-13.

Duno de Stefano, R., R. Riina \& P.E. Berry (2002). Pleurisanthes howardii (Icacinaceae), a new species from the Venezuelan Guayana. Harvard Papers in Botany 7: 13-15.

Engler, G. (1897) Icacinaceae. In: Von Martius, C.F.P. [ed.] Flora brasiliensis XII (2). Fleischer, Münich and Leipzig, pp. 4161.

Engler, G.A. (1893) Icacinaceae. In: Engler, A. \& Prantl, K. [eds.] Die Natürlichen Pflanzenfamilien III (5). Engelmann, Leipzig, pp. 233-257, 459-460.

Edgar, R.C. (2004) MUSCLE: multiple sequence alignment with high accuracy and high throughput. Nucleic Acids Research 32: 1792-97. http://dx.doi.org/10.1093/nar/gkh340

ESRI (1999) ArcView GIS. Environmental Systems Research Institute, New York. Available: http://www.Esri.com

Goloboff, P.A., Farris, J.S. \& Nixon, K.C. (2003) TNT: tree analysis using new technology. v. 1.0. Program and documentation available at http://www.zmuc.dk/public/phylogeny.

Greenman, J. M. \& C. H. Thompson. (1914[1915]) Diagnoses of flowering plants, chiefly from the southwestern United States and Mexico. Annals of the Missouri Botanical Garden 1: 405-418. http://dx.doi.org/10.2307/2990140

Grisebach, A.H.R. (1866) Catalogus plantarum cubensis. Engelmann, Leipzig, 301 pp.

Hassler, É. (1913). Ex herbario Hassleriano: Novitates paraguarienses. XVII. Repertorium Specierum Novarum Regni Vegetabilis 12(322/324): 249-255.

Hijmans, R.J., Guarino, L., Bussink, C., Mathur, P., Cruz, M., Barrentes, I. \& Rojas E. (2004) DIVA-GIS, version. 5.0. A geographic information system for the analysis of species distribution data. Available at http://www.diva-gis.org (free access)

Hooker, W. J. (1830) Illustrations of Indian botany, principally of the southern part of the peninsula. Botanical Miscellany 2: 107.

Howard, R.A. (1942) Studies of the Icacinaceae, II. Humirianthera, Leretia,

Mappia and Nothapodytes, valid genera of the Icacinaceae. Journal of the Arnold Arboretum 23: 55-78.

Howard, R.A. (1976) Icacinaceae. In: R. Woodson Jr., R. W. Schery \& collaborators [eds] Flora of Panama. Annals of Missouri Botanical Garden 63: 399-418.

House, H. D. Nomenclatorial notes on certain American plants--II. The American Midland Naturalist 8: 61-64.

Liogier, A.H. (1953) Flora de Cuba 3. Dicotiledóneas: Malpighiaceae a Myrtaceae. Contribuciones ocasionales del Museo de Historia Natural del Colegio de La Salle. Editorial de la Universidad de Puerto Rico, 502 pp.

International Union for Conservation of Nature and Natural Resources (IUCN) (2001) IUCN Red List Categories and Criteria, Version 3.1. IUCN, Gland, Switzerland and Cambridge, United Kingdom, http://www.iucn.org.

Jacquin, N.J. (1787) Icones plantarum rariorum 1. Wappler, Vienna, 20 pp, 200 plates.

Jussieu, A. H.L. (1823) Description d'un genre nouveae nommé Icacina. Mémoires de la Société d'Histoire Naturelle de Paris 1: $174-178$.

Kårehed, J. (2001) Multiple origins of the tropical forest tree family Icacinaceae. American Journal of Botany 88: 2259-2274. http://dx.doi.org/10.2307/3558388 
Lundell, C.L. (1942) Studies of American spermatophytes-II. Contributions from the University of Michigan Herbarium 7: 154.

Lundell, C.L. (1970) Studies of American plants II. Wrightia 4: 139-140.

Macfadyen, J. (1837) The flora of Jamaica. 1. Longman, Orme, Brown, Green \& Longmans, London, 351 pp.

Manchester, S.R. (1994) Fruits and seeds of the middle Eocene Nut Beds flora, Clarno Formation, Oregon. Palaeontographica Americana 58: 1-205.

Miers, J. (1852) Observations on the affinities of the Icacinaceae. Annals and Magazine of Natural History, second series 9: 109-119, 359-367, 387-399.

Murray, J.A. (1748) Systema vegetabilium. Dieterich, Göttingen, 1004 pp.

Olivier, D. (1868) Flora of tropical Africa 1: 1-479. Reeve, London.

Olmstead, R.G. \& Sweere, J.A. (1994) Combining data in phylogenetic systematics: an empirical approach using three molecular data sets in the Solanaceae. Systematic Biology 43: 467-481. http://dx.doi.org/10.1093/sysbio/43.4.467

Pierre, J.B.L. (1892). Flore forestière de la Cochinchine. Doin, Paris, 300 pp.

Pigg, K. B., Manchester, S. R. \& DeVore, M. (2008) Fruits of Icacinaceae (tribe Iodeae) from the Late Paleocene of western North America. American Journal of Botany 95: 824-832. http://dx.doi.org/10.3732/ajb.2007340

Rambaut, A. (1996) Se-Alv2.0a11: sequence alignment editor. Available from: http://evolve.zoo.ox.ac.uk/.

Rankin B.D., Stockey R.A. \& Beard, G. (2008) Fruits of Icacinaceae from the Eocene Appian Way locality of Vancouver Island, British Columbia. International Journal of Plant Sciences 169: 305-314. http://dx.doi.org/10.1086/523876

Reid, E.M. \& Chandler, M.E.J. (1933) The London Clay flora. British Museum (Natural History), London, 561 pp.

Robinson, B.L. \& Greenman, J.M. (1895) New and noteworthy plants chiefly from Oaxaca collected by Messrs. C. G. Pringle, L. C. Smith and E. W. Nelson. American Journal of Science, and Arts, ser. 3 50: 150-168.

Sleumer, H. (1940) Beitrage zur Kenntnis der Icacinaceen und Peripterygiaceen. Notizblatt des Botanischen Gartens und Museums zu Berlin-Dahlem 15: 228-257. http://dx.doi.org/10.2307/3995114

Sleumer, H. (1942) Icacinaceae. In: Engler, A. [ed.] Die natürlichen Pflanzenfamilien, 2nd ed., 20b. Engelmann, Leipzig, pp. 322-396.

Stamatakis, A. (2006) RAxML-VI-HPC: maximum likelihood-based phylogenetic analysis with thousands of taxa and mixed models. Bioinformatics 22: 2688-2690. http://dx.doi.org/10.1093/bioinformatics/btl446

Stull, G.W, Moore, B.R. \& Manchester, S.R. (2011) Fruits of Icacinaceae from the Eocene of southeastern North America and their biogeographic implications. International Journal of Plant Sciences 172: 935-947. http://dx.doi.org/10.1086/660877

Stull, G.W., Herrera F., Manchester, S.R., Jaramillo, C. \& Tiffney, B.H. (2012) Fruits of an "Old World" tribe (Phytocreneae; Icacinaceae) from the Paleogene of North and South America. Systematic Botany 37: 784-794.

Swofford, D.L. (2003) PAUP*. Phylogenetic analysis using parsimony (*and other methods). Version 4. Sinauer, Sunderland.

Systematic Association Committee for Descriptive Biological Terminology. (1962) Report of the Systematics Association Committee for Descriptive Biological Termi- nology, II and IIa. Terminology of simple symmetrical plane shapes (Charts 1, la). Taxon 11: 145-155, 245-247.

Thiers, B. (2010 and onwards) Index herbariorum: A global directory of public herbaria and associated staff. New York Botanical Garden's Virtual Herbarium, New York. Available from: http://sweetgum.nybg.org/ih/ (accessed: 20 January 2012).

Urban, I. (1912) Symbolae Antillanae seu fundamenta florae indice occidentalis 7. Gebru der Borntraeger, Berlin. 161-304 pp.

Vellozo, J.M.C. (1829) Florae flumiensis. Machado, Rio de Janeiro, 352 pp.

Wallich, N. (1831) Plantae Asiaticae rariores 3. Treuttel, Würtz \& Ritcher, London, 117 pp.

Wight, R. (1843-1845) Icacincaeae. In: Icones plantarum Indiae Orientalis vol. 3. Hunt, American Mission Press, Calutta \& London, pp. 737-1046.

Wiens, J.J. (2003) Missing data, incomplete taxa, and phylogenetic accuracy. Systematic Biology 52: 528-538. http://dx.doi.org/10.1080/10635150390218330

Wiens, J.J. (2009) Paleontology, genomics, and combined-data phylogenetics: can molecular data improve phylogeny estimation for fossil taxa? Systematic Biology 58: 87-99.

http://dx.doi.org/10.1093/sysbio/syp012 
Appendix 1. GenBank accession numbers for the $n d h F$ accessions included in this study.

Sequences newly generated for this study are noted with an asterix. Accessions of Icacinaceae s.s. are organized according to the group scheme of Kårehed (2001). Additional taxa (including Garryales and outgroups) are organized alphabetically by genus.

ICACINACEAE S.S. Apodytes group: Apodytes dimidiata (AJ429109), Rhaphiostylis beninensis (AJ312958); Cassinopsis group: Cassinopsis ilicifolia (AJ429110), Cassinopsis sp. (AJ312962); Icacina group: Alsodeiopsis senegalensis (AJ312953), Icacina mannii (AJ400888), Icacina senegalensis (AJ429111), Iodes liberica (AJ312947), *Lavigeria macrocarpum (KF146235), *Leretia cordata (KF146232), *Mappia mexicana (KF146234), *Mappia multiflora (KF146229), Mappia racemosa (AJ312959), Nothapodytes foetida (AJ312960), Phytocrene oblonga (AJ312968), Pyrenacantha grandifolia (AJ312956), Pyrenacantha malvifolia (AJ312952), Stachyanthus zenkeri (AJ312967); Emmotum group: *Calatola cf. venezuelana (KF146233), Emmotum nitens (AJ312965), *Oecopetalum mexicanum (KF146230), *Ottoschulzia pallida (KF146228), Ottoschulzia pallida (AJ312966), *Ottoschulzia rhodoxylon (KF146231).

ADDITIONAL TAXA. Aucuba japonica (AY725869), Borago officinalis (L36393), Eucommia ulmoides (AJ429113), Garrya elliptica (AF147714), Gelsemium sempervirens (AF130170), Ilex crenata (AF130206), Jasminum mesnyi (AF130162), Lamium purpureum (U78694), Solanum tuberosum (L76287), Vahlia capensis (AJ429112). 